\title{
Democratic Transition Research: From Western to Post-Soviet East European Scholarship
}

\author{
Olga Oleinikova
}

University of Technology Sydney

\begin{abstract}
This paper is the first of its kind to provide a comparative overview of Western (Western European and North American) and post-Soviet East European transition theories and literature that can be used to understand specifics of postSoviet transition in Eastern Europe. Bridging the two broad theoretical traditions of East and West, and taking Ukraine as a case study, this literature review adds to the transition literature a discussion that relates to the emergence and interplay of structure and agency theories since the 1950s. In particular, the review sets out the various ways in which the transition from post-Communist government to democracy has been theorized, from a structuralist to an agency-structure approach. Meanwhile, it puts new wind into the sails of the idea that the interplay of structure and agency is more relevant to understanding the transition in Ukraine-reflecting similar dynamics in other post-Communist Eastern European states. This review is a good starting source for those who want to understand the roots of democratic transition research and theories.
\end{abstract}

Keywords: transition scholarship, theory, agency, structure, Ukraine, democracy.

\section{INTRODUCTION}

$\mathrm{T}^{\mathrm{h}}$ he present era of democratization as the new social reality, which is believed to be the dominant trend in current social and political processes in the advanced and democratically developed West, has advanced differently in post-Soviet Eastern Europe (Sztompka 450; Toffler 55; Bauman 96). The fact that the former Soviet countries have shifted to democratic political regimes, and correspondingly to their capitalist economic systems, has often been overshadowed by other domestic factors and is still waiting to receive proper attention in the mainstream literature and transition scholarship. By the same token, most attempts by post-Soviet Eastern European countries to create market economies have proved problematic. Twenty years of steady promotion of democratic reforms and efforts to repudiate the structural legacies of the Communist past have not produced significant and stable levels of democracy. This is revealed by only semi-democratic forms of decision-making at the state level in Ukraine, Russia, Belarus, and Moldova, along with a sharp socio-economic differentiation among their social groups. Consequently, growing 
disenchantment with pro-democracy messaging and democratization measures in a majority of the young post-Communist democracies has led to widespread skepticism (at least at the level of theoretical thought) about democratization being useful and the only prospective and sustainable mode for social development. By "democratization" I mean not only the political transition and introduction of a democratic system and principles in postauthoritarian states of Eastern Europe, but a way of life committed to greater equality and public accountability of power that rests on history, civil society, economic development, and associated individual agency and structural shifts. Indeed, various studies have questioned whether structural changes have had any positive outcomes in post-Communist Eastern European countries (Carothers, "The End," 7; Knack 257; Burnell 100; Merkel, Systemtransformation 63).

Given the limits of current transition research and the lack of a clear paradigm for understanding what is happening politically and socially in post-Soviet Eastern European societies, there is a need for a different and comparative approach, which would widen our understanding of societies in transition in terms of "the deeper, spontaneous shifts typical for social and individual consciousness that find expression primarily in the transformation of the value system and in the formation of new individual life strategies and agency" (Naumova 7). ${ }^{1}$ Currently, a different approach that would consider the interplay and combination between structure and agency is rarely applied to understand the empirical reality of modern postCommunist states. By "agency" I mean the capacity of individuals to act independently and to make their own free choices. A useful and initial definition was given by Anthony Giddens and is utilized in this essay: the ability of individuals to "intervene in the world, or to refrain from such intervention, with the effect of influencing a specific process of state of affairs" (14). Later, Carter and New extended Giddens's definition, adding notions such as "self-consciousness, reflexivity, intentionality, cognition, emotionality" (4). These characteristics are contrasted with "social structures," defined as "systems of lasting relationships among social positions" (Porpora, qtd. in Mrozowicki 55).

This article presents a comparative exploration of transition research in Western scholarship (understood herein as Western European and North American literature) and post-Soviet East European scholarship (Ukrainian and Russian literature). This literature review is the first of its kind. The literature analyzed in this review was selected based on the criteria of its application of the agency/structure theories. This review attempts to fill a major gap in transition research by bridging the Western and Eastern

\footnotetext{
${ }^{1}$ All translations are my own.
} 
European perspectives and theorizing democratic transition in relation to the emergence and interplay of structure and agency theories. Taking Ukraine as a central case study, this review puts new wind into the sails of the idea that the interplay of structure and agency is more relevant, rather than a focus only on either the individual or on structure, for understanding the social transformations that have taken place within post-Communist democratic reforms in Eastern Europe. Both structure and agency are also relevant to understanding the current transitional dynamics in the region.

The article is organized as follows. First, it presents a historical overview of the interplay between agency and structure perspectives in Western and post-Soviet East European transition scholarship, which resembles a circuit where these approaches exclude or substitute for one another, or combine or integrate with one another. Second, this paper takes a closer look at the theoretical approaches and models that explain the essence of the equal importance of agency and structure in understanding the dynamics of postSoviet transition and democratization processes in Ukraine. Further, the second section of the paper presents some insights into the transition dynamics in post-independence Ukraine. In conclusion, the paper summarizes the key points and limitations of the extant transition scholarship and puts forward the idea that a combined structure-agency perspective bears more fruit in capturing empirically and explaining theoretically the long-term effects of social change at the individual and collective levels, as well as their residual effects on structural transformations.

\section{STRUCTURE AND AgENCY PERSPECTIVES Within TRANSITION RESEARCH (1950S TO THE LATE 2000s)}

Historically, the interplay between agency and structure perspectives in transition scholarship resembles a circuit, where these approaches exclude or substitute for one another, or combine or integrate with one another. This logic of circulation of these two approaches in transition research (see Figure 1) requires us to reflect on the origins of transition scholarship and its usefulness in understanding post-Soviet transitions in Ukraine. 
Figure 1. History of circulation of structure and agency perspectives within transition research (1950s-late 2000s)

\section{Western Approach:}

1) Structure-centred (1950s-60s)

2) Agency-centred (1980s)

3) Structure-centred (1990s)
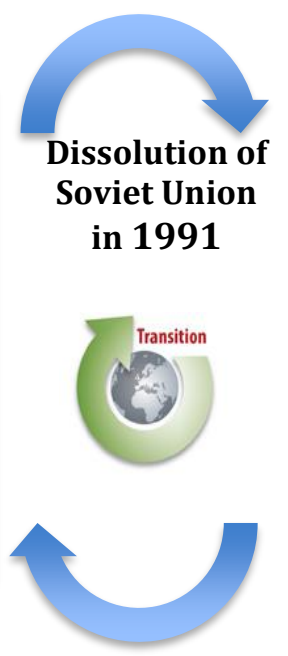

Post-Soviet Approach:

1) Structurecentred (late 1980s-late 1990s)

2) Structure-agency (mid-2000s-late 2000s)

Transition research starts in the early 1950s-60s in the West, at a time "when democratic forms of government were the exception rather than the rule" (Wucherpfennig and Deutsch 1). Seymour Lipset, an early theorist in the field, introduced what he called the "requisites of democracy" ("Some Social Requisites," 74). By doing so, he contributed the first formative input and laid out the transition research agenda for generations to come. He established the first theoretical link between the level of development of a given country and its probability of being democratic. Under "requisites of democracy" Lipset described the foundations for successful democratic consolidation, which he saw as variables that create conditions favourable for democratization and economic development (modernization)-such as urbanization, wealth, and education ("Some Social Requisites," 77).

Concerned with structural and societal conditions conducive to democracy, especially in socio-economic terms, Lipset outlined a structurecentred framework that analyzed transitions in terms of economic development and legitimacy ("Some Social Requisites," 100). He argued that these two key structural characteristics were necessary to sustain democratic political systems (he used the examples of European and English-speaking nations and Latin American nations). Lipset's idea that economic modernization leads to democracy ("Some Social Requisites," 83) was further developed by Rostow (99) and Deutsch (493), who theorized that the path from economic modernization to democracy is linear and inevitable. Rostow (81) was later criticized by Moore (35), who formulated 
a historical analysis and critique in which structural transformations caused by socio-economic development (industrialization) were not necessarily conducive to democracy.

Contrary to the modernization approaches of the 1950s-60s that were concerned with structural transitions, at the beginning of the 1980s Western research on transition was driven by the agency-centred perspective propagated specifically in the writings of O'Donnell and others (20). The retrospective analysis of transition research undertaken by 0'Donnell and others (25) helped scholars to understand that incorporating concepts such as human agency -in addition to the structural factors-bears more fruit. 0 'Donnell and others (78) discuss that the factors influencing the success or failure of transitions revolve around the ruling elite as the driving force that initiates shifts at all levels. They believe that any type of transition is possible if the relevant elite groups (ruling and opposition) could agree on common ways of implementing democracy (O'Donnell et al. 34). The earlier socioeconomic conditions (Lipset, "The Social Requisites of Democracy," 4; Lerner 58; Rostow 43; Moore 70) were understood as being irrelevant for transition research (Merkel, Systemtransformation 26).

In Eastern Europe at that time (1980s), no similar research was being done, as few scholars could even conceive of a possible future shift from Communism to democracy that would actually necessitate research on transition. Any work on Eastern Europe was done in the West. Interestingly, though, around the same time at the end of the USSR, the Western agency perspective faced challenges in the form of a wave of "structuralism and the wave of pessimism" toward democracy (Merkel, "Embedded," 34). The main focus of Western theoretical explanations of transition shifted from agency back to structure-centred transition theories, and Eastern European scholars were part of this rethink. Merkel argued that scholars such as O'Donnell and Schmitter overestimated the power of political elites (Systemtransformation 62). The belief that democracy can be promoted, supported or even imposed from the outside began to dominate (Merkel, Systemtransformation 436). Agency perspectives in the form of action theory were claimed to have shown themselves to be deficient in the analysis of the political and socio-economic system transformations that overwhelmed post-Communist Eastern Europe. The works of Merkel (Systemtransformation 27), Carothers ("How Democracies Emerge," 15), Ottaway (316), Levitsky and Way (55), and Nathan (8) are indicative of the shift in focus of transition research from an actor-centred perspective to a structuralist perspective. These works also highlight the shifts in the perception of ordinary citizens of the democratic changes in new post-Soviet democracies from optimistic attitudes in the early 1990s to more pessimistic attitudes that have been increasingly common since the 2000s. 
Therefore, in the first years after the dissolution of the Soviet Union and Communism's collapse, most studies of state transition to markets and democracy, which tended to emerge from the West, were rather formal and structural, as more and more Western scholars without contextual expertise identified post-Communist Eastern Europe as the natural laboratory for testing their generalizing transition theories. The authors of the new wave of Western theories explaining transition (Mansfield \& Snyder 302; Zakaria 21; McFaul et al. 33; Acemoglu and Robinson 54) tried to take into account some of the features of the post-Soviet countries; for example, they sought explanations for the development of modernity in the history of particular countries. These scholars emphasized the negative role of the Soviet legacy as a factor that not only inhibits processes of liberal democratization but makes it impossible to even apply the general theoretical concepts of democratization to the post-Communist region. Their assessment of the current state of affairs in post-Soviet countries was pessimistic, although they did not neglect the possibility of a gradual change towards democratization.

This led to significant debate, especially in the political and social sciences, about the relative value of these Western studies for providing an analysis of post-Soviet transition towards democracy. Much of the contestation hinged upon how much one needed to know about national and local culture and history to produce a good explanatory framework.

The first scholarly works on transition in the post-Soviet East European scholarship appeared relatively recently, after 1990, when there finally appeared a real need to understand the consequences of reforms and transitions from the inside. The first research on transition in postCommunist countries was determined by the dominant structural paradigm, which was drawn from existing research in the Western tradition. The postSoviet social sciences in the late 1980s and early 1990s favoured the authority of Western theories, and applied them almost without adaptation to analyses of the post-Soviet social reality. These theories included path dependence theory² (Pierson 255; Mahoney 530; Collier and Collier 67), the

\footnotetext{
2 "Path dependence" is an important concept for social scientists engaged in studying processes of change. Being based on models of technological development used in economics, the first wave of scholarship in political science and sociology applied the concept of path dependence to political institutions, emphasizing locked-in and increasing returns (Pierson 257), self-reinforcing sequences (Mahoney 514), and the "mechanisms of reproduction" of particular historical legacies (Collier and Collier 66). These works played an important role in building arguments about historical causation and interdependency of global development, when less developed countries follow the progression logic of more advanced states with successful democracies. Referring to the social developmental sequences, this concept was later
} 
third wave of democratization theory ${ }^{3}$ (Huntington 28), and political mobilization theory. ${ }^{4}$

Furthermore, theories of modernization were revived to explain democratic transition in post-Soviet countries. This involved dominant discourses such as "catching up" with processes of modernization and westernization, the need for development, overcoming dependency, and reforming the state. In searching for their own approach, post-Soviet scholars started to apply and develop early ideas about the path from economic modernization to democracy, and to empirically test the relationship between democracy and economic development. As in the early 1950s through the 1960s (Lipset, "Some Social Requisites," 70; Rostow 49; Moore 55), structural factors-such as the degree of development of national economies, the power of social classes, the autonomy of the state, and the efficiency of its bureaucracy-once again became central to the research on system transformations (Merkel, Systemtransformation 28). Despite the fact that the critique of modernization theory from the Third World was severe (Frank 49; Roxborough, Theories of Underdevelopment 71) - in terms of promoting the paternalism of developed states over underdeveloped states-Pye (6) and Lipset and others (160) proclaimed the renaissance of a series of modernization theories by Roxborough ("Modernization Theory," 758), Lipset ("The Social Requisites," 5) and Moore (91) in the post-Soviet democratization and transition theoretical discourse. In 1999 Zaslavskaia, a Russian scholar influenced by Roxborough ("Modernization Theory," 755), described "modernization in post-Soviet countries as contributing to a growing capacity for social transformations" (Zaslavskaia 15). In this approach the argument was that underdeveloped post-Soviet states, in terms of democracy and market economy, are subject to social transitions only through structural modernization effects.

\footnotetext{
labelled "path dependent social dynamics" (Blume and Durlauf 15; Durlauf and Young 21). The path dependence theory of democracy was harshly criticized for overstating the degree of institutional stability of the exemplar democratic states (Thelen 438; Hacker 34; Crouch and Farrell 16; Schwartz 256; Alexander 45).

${ }^{3}$ Huntington argued that international structural factors during the 1970 s were the causal sources for initiating Third-Wave democracy (5). Under structural factors he meant the "regional contingency factor" — or the Soviet equivalent of the "domino theory," where the success of democracy in one country causes other countries to democratize. He suggested that post-Soviet states are being influenced by democratization effects, most notably by the efforts to spread democracy by the European Union and the United States.

4 Political mobilization is a framework that is utilized to understand political participation in a transition period.
} 
Post-Soviet structuralist scholars argued that a positive feature of the modernization theory was the emphasis on, and concrete analysis of, a wide range of modernization processes that took place immediately after the collapse of Soviet rule: urbanization, industrialization, rationalization, secularization, marketization of the economy, democratization policy, the progress of education, and other cultural processes. In other words, it suggested a framework for the interconnected study of all major aspects of social development that took place in post-Soviet countries. An important step in the development and application of modernization theory in the postsocialist countries was undertaken by well-known scientists and sociologists in Hungary (Andorka and Spéder 22), Poland (Adamski 61; Domański 465), the Czech Republic (Keller and Westerholm 50; Machonin 15), and Germany (Zapf 18). These scholars, applying modernization theory to the post-Soviet context, ended up criticizing it for its failure to reflect the multidimensionality of the transition process and for its limited explanation of structural and cultural factors in the development of post-socialist countries of Central and Eastern Europe. Their criticism even extended to the updated and renewed versions of the "catching-up" and "reflexive" modernization theories proposed by Beck and colleagues (20; see also Keller 49).

Therefore, the more research was done using modernization theories to understand social change in post-Soviet countries, the more problems they encountered and the more concerns post-Soviet scholars had. These critiques of modernization theories and their applicability to the post-Soviet transition context were based on the argument that they did not sufficiently explain the nature of the structural shifts that were taking place in postSoviet space "simply because the historical vector of these changes was not objectively set up, not preconditioned" (Iadov 67).

This growing critique of modernization theory was further escalated after the release of a provocative series of publications by Przeworski and others in the West, questioning the relationship between development and the transition to democracy (31). It was argued that economic factors alone are not sufficient to account for the fates of democratic and authoritarian regimes. The theories emphasizing the role of economic growth (Lipset, "The Social Requisites," 4; Przeworski et al. 26) were replaced in the West, as well as in post-Soviet scholarship, by more moderate concepts. These include the concept of gradual transition (O'Donnell et al. 86; Carother, "How Democracies Emerge," 17), where the transition is understood to gradually develop from a time of "liberalization" to "democratization," followed by the deepening of democracy and its adoption by all social groups at the stage of socialization. This latter stage provides a transition to a more "stable" democracy, which is the ultimate goal of transition. As Carother suggests, "gradual transition" is based on a recognition of the possibility and 
inevitability of constant evolutionary change towards democracy, even in those countries with strong authoritarian regimes ("The End," 6).

In one form or another, Western structure-centred theories of transition have long been among the decisive explanations and conceptualizations influencing the writing of theoreticians and sociologists, and of economists and social reformers, in post-Soviet Eastern Europe (Kutsenko, "Fazy i puti," 260; Babenko, "Sotsial'nyi mekhanizm postsovetskoi transformatsii"). Given the rapidly changing preferences of post-Soviet scholars to follow Western research trends in analyzing changes in, and prospects for, political development, it can be argued that the primary post-Soviet research on transition failed to facilitate a deep understanding and explanation of the post-Soviet development of democracy.

Russian and Ukrainian scholars argue that given the limits of the structural transition paradigm of the 1990s for understanding what is happening in post-Soviet societies, and in Ukraine in particular, there is a need for a different approach, with more of a focus on agency that would explain the structural shifts that are related to changes at the level of agency (micro-level) (Naumova 5; Zlobina 33). Naumova explains that a new theory should be able to widen our understanding of societies in transition to include deeper, spontaneous shifts in social and individual consciousness that find expression primarily in the transformation of the value system and in the formation of new, individual life strategies (7).

Subsequently, by the beginning of the new century in the post-Soviet countries, scholars had begun to create theories related to the cultural and historical originality of post-Soviet people to explain the unique historical development of political tradition, national mentality, and cultural heritage (Titarenko 23; Kohn et al. 141). At the start of the 2000s post-Soviet scholars made significant advances in empirical descriptions and conceptualizations of post-Communist transitions. These scholars suggest that the most theoretically pertinent way to approach the interrelationship between the components of transformation processes in the post-Soviet space is to focus on: (1) targeted reforms of basic institutions; (2) semi-natural changes in the social structure and change in agency (Zaslavskaia and Iadov 10; Kutsenko, "Fazy i puti," 261; Golovakha and Panina 40; Kohn et al. 138; Panina 26). However, it should be noted that such studies of the interrelationship of these combinations of structure and agency are still relatively rare.

The addition of agency to the structuralist model of transition gave birth to the conceptual unity of agency-structure that has become the main theoretical model in post-Soviet transition research from the mid-2000s onwards. The combined agency-structure approach was primarily used to understand transition through the study of agents of social change. By discussing in more detail the combined agency-structure approach, in the 
following section I attempt to understand the broader dynamics and transition in the case of post-independence Ukraine.

AgENCY AND STRUCTURE: THE COMBINED APPROACH IN UNDERSTANDING TRANSITION IN UKRAINE

Drawing on the transition scholarship outlined above, I shall argue here that agency and structure are both equally important in understanding current post-Soviet transition and democratization processes in Ukraine.

The first attempts in the transition scholarship to bring structure and agency together were related to the concept of social action, which was the basis of the voluntaristic approach. In the 1980s and early 1990s, for the first time in its history transition research began to be equally committed to voluntarism and structuralism. This paradox generated a variety of attempts to view structure and agency as mutually constitutive. The ground-breaking approach to the combination of structure and agency was made by Giddens in his work on the theory of structuration, where he describes structure and agency theories as two sides of the same coin: structures make social action possible, and social action creates and transforms structures. Giddens calls it the "duality of structure" and develops a stratification model of social action (19). According to Giddens's "stratification model of human action," individuals are knowledgeable within the constraints and opportunities presented by social structures (5). Their knowledge is distributed at three levels of consciousness. First there is the unconscious, where motivations cannot be articulated; second, practical consciousness, where knowledge of personal motivations and institutional rules/resources can be exploited to provide a rationale for action but cannot readily be verbalized; and third, discursive consciousness, where knowledge can be employed and communicated in a verbal explanation.

These ideas of the mutual determination of agency and structure were revived during the mid- to late 2000s in post-Soviet studies on transition, particularly in the works of Zaslavskaia (17), Panina (22, 24, 50-56), Babenko ("Sotsial'nyi mekhanizm transformatsii," 119), Kutsenko and Babenko (25), Kutsenko ("Deiatel'nostnaia perspektiva," 28; "Fazy i puti," 262), and Petrushyna (15). These works have strongly established the agency-structure approach in post-Soviet social science. In the mid-2000s, Tat'iana Zaslavskaia introduced her own model of social transition in postSoviet states that brought together the mutual determination of agency and structure, based on twenty years of research and experiments conducted in Russian society. Ol'ha Kutsenko, an outstanding Ukrainian scholar who applied Zaslavskaia's theories to develop her own class-system approach, has defined Zaslavskaia's work as a model that is "built on the understanding 
of the fundamental place of social action in society and its dynamic structural conditionality and important role of the self-organizing processes in social dynamics" (Kutsenko, "Fazy i puti," 253). In Zaslavskaia's model, the agency factor of social change comes first. Structural factors, according to Zaslavskaia, limit the transformational activity of agents; at the same time, they are its product and result.

Following the developments of Zaslavskaia's research, the Ukrainian sociologist Nataliia Panina has contributed to the structure-agency perspective, which was becoming established and increasingly popular in post-Soviet scholarship since the 2000s. Panina introduced her own original theory of the post-Soviet transition of Ukrainian society, based on a normative-personal concept of Ukrainian social transition. According to this concept, the institutional changes in the transition society are conditioned by the set of values of the social actors and their personal resources, which define their strategies of adaptation to the changing environment. This, in turn, causes shifts in lifestyles and in the nature of their activities. The routinization of these new social practices and the formation of new normative value systems result in the emergence of new institutions that correspond to the declared aims of the democratic development of Ukrainian society (Panina 20). Panina asserts that this complex model offers a holistic theoretical and methodological model to study Ukrainian transition processes from a structure-agency perspective.

Many Ukrainian scholars have applied Panina's methodological developments and Zaslavskaia's model of societal transition and elements of her structure-agency perspective in their own theories. Svitlana Babenko relied on Zaslavskaia's conclusions while studying the social mechanisms of post-Soviet social transitions ("Sotsial'nyi mekhanizm," 262). Kutsenko has employed Zaslavskaia's structure-agency framework in her study of class formation and exploration of system transformations in former Soviet-bloc countries ("Fazy i puti," 253). Petrushyna has referenced Zaslavskaia's work in her study of the socio-economic behaviour of Ukrainian citizens in conditions of institutional change (16). Finally, Iurii Reznik has explored the factors and methods involved in implementing civic practices in transition societies through the prism of Zaslavskaia's concepts (11).

With the aim of a deeper understanding of the civic practices and agency part of the transition, leading Ukrainian and Russian scholars very often apply the concept of life strategy (Reznik 17; Babenko, "Sotsial'nyi mekhanizm postsovetskoi transformatsii," 265). This concept was brought to Soviet sociology in the 1960s and became a popular field of study in the post-Soviet scholarly period of the 1990s. As per Reznik and Smirnov, life strategy is a "dynamic system of long-term orientation of the individual, including a change (formation) in accordance with a specific plan and given terms of socio-cultural development" (99). The key idea here is the dynamic 
life strategy component of change. Its relevance was driven by the need to explain the social factors of the crisis of social values that emerged in the post-Soviet transitional stage, as well as the population's behavioural reaction to the ongoing transition. Previously, sociologists studying the transformation processes would interpret the processes of social change in terms of historically defined trajectories, referring to the analysis of results, not processes.

In order to better understand the theoretical debate on post-Communist transition, it is worthwhile at this point to broadly describe some of the features of the Ukrainian case in the context of existing theories and of the combined structure-agency theoretical paradigms explaining transition in Ukraine.

\section{TRANSITION PROCESSES WITHIN UKRAINIAN SOCIETY}

From the early years of transition from authoritarianism towards democratic governance until the recent events of post-Euromaidan Revolution, the transition processes within Ukrainian society have demonstrated very active promotion of democratic values and freedoms. Along with still-present authoritarian practices as well as market reforms and a nationalist revival, these processes have significantly influenced the behaviour of Ukrainians and related structural transformations. Contemporary democratic transition in Ukraine has been characterized as being affected by social disintegration, shifts in values, and the formation of a new structure of social relations. For more than 27 years now since the collapse of the USSR in 1991, Ukraine has continued to struggle to become a successful democratic state. There have been a number of democratic achievements in Ukraine at both civic and administrative levels during its years of independence. But unfortunately, they are more nominal than real. Following its independence, Ukraine's government proclaimed its commitment to the protection and promotion of common fundamental values of democracy, human rights, and the rule of law. Civil society has been strengthened and there was even an attempt to turn it into a new force behind Ukrainian democratic reform efforts. However, all these attempts have been significantly hindered by several main obstacles. Each successive Ukrainian government, including the one which came to power in the time of the Euromaidan Revolution (2013-14), has demonstratively been eroded by corruption, nepotism, and a state-centric vision of Ukraine's future that has created more structural constraints rather than empowered the formation and activation of agency in Ukrainian society.

One of the core effects of the post-Soviet transition in Ukraine was a polarization of the life strategies adopted by Ukrainian citizens in response 
to their changed economic, political, and social situations resulting from the structural transformations. Since the early 1990s the analysis of post-Soviet social reality has spawned a series of widely used terms that capture this polarization of life strategies, such as survival strategies and adaptation strategies-as opposed to the notion of strategies for achievement. In the late 1990s, the Ukrainian scholars Olena Zlobina and Volodymyr Tykhonovych built a model of the life strategies based on the dichotomy of survival strategy and a strategy of achievement or "life creation" (21). They argue that the basis of a given life strategy is the level of adaptation to structural constraints, from voluntary "successful and positive" to "forced" adaptation. The dichotomy between the two main life strategies can be read in terms of strong agency (key to the achievement life strategy) versus weak agency (present in survival life strategies with forced adaptation).

Zlobina, head of the Department of Social Psychology at the Institute of Sociology of the National Academy of Sciences of Ukraine (NASU), reported in March 2013 that " $27 \%$ of Ukrainians apply adaptation strategies; $32 \%$ apply avoidance/exclusion. Another 25\% have an undefined life strategy" ("Dolia derzhavy"). Referring to data from the study "Ukrains'ke suspil'stvo: Monitorynh sotsial'nykh zmin" ("Ukrainian Society: Monitoring Social Change"), 5 she also noted that recently the cohort of people using the strategy of avoidance/exclusion is steadily decreasing, from 45\% in 1997 to $32 \%$ in 2012. There was also a noticeable decline in the group of Ukrainians figured as adapting, from $36 \%$ in 2003 to $27 \%$ in 2012. Meanwhile, the group of those who mastered the transition doubled, from $8 \%$ to $16 \%$ and then remained quantitatively almost unchanged ("Dolia derzhavy").

Analyzing the data obtained through Ukrainian transition research shows that 1992-98 (especially 1992-96) were the toughest years of radical social transition, characterized by anomie, deinstitutionalization and macro involution, and uncertainty in formation of a new social order. The prolonged systemic crisis that overwhelmed Ukrainian society in the first decade of transition affected the moral and psychological atmosphere in the country. There was a permanent decline in economic production and, consequently, a decline in people's overall well-being. A lifestyle of survival became the norm for most of the population. Since salaries and pensions were extremely small, payments could only meet the basic and urgent needs for food, clothing, and home maintenance. The people's main task was, and is still, to manage their lives-that is, to survive physically and help those

5 "Ukrainian Society: Monitoring Social Change" is an annual social project coordinated by the NASU Institute of Sociology since 1992. It consists of a survey of the Ukrainian population with a sampling of about 1,800 respondents (aged over 18), and representation parameters such as gender, age, education, region, and type of settlement. The Socis Centre conducts the fieldwork. 
who were dependent on them. All other needs-cultural, spiritual, recreational, and cognitive-were postponed for the future. In sum, the first two decades of independence turned out to be an extremely hard time for all population groups, whose life strategies were mostly passive and survivaloriented, with weak agency constrained by social structures. This was reflected in the widespread use (as captured by numerous empirical studies and surveys) of strategies of exclusion/avoidance, survival, and an indefinable state of mind. Risk-minimizing and survival-oriented strategy, defined by weak agency and domination of structure, were typical for Ukraine up until the Euromaidan Revolution of 2013.

The 2013-14 Euromaidan Revolution demonstrated an enormously significant activation of civil society and pro-democracy groups, which took an active position and actions to accelerate democratization processes in Ukraine. Despite the activation of agency and its growing strength to effect structural transformations, the social structure of contemporary Ukrainian society remains a hybrid system of mutually penetrating types of social homogeneity and inequality resulting from the social changes of the last 27 years. There is a significant gap between social groups who have high life chances and groups whose life chances are very restricted by local opportunities (the major part of society). The present economic and social well-being of the majority of Ukrainians today determines their choices to adopt exclusion, survival, or adaptation life strategies, but rarely the achievement ones. Those values, attitudes, and life strategies that are institutionalized in society shape the limits of possible change of the structural system. Yet it is only the achievement strategy-which has been shown by several studies to be not relevant for the majority of Ukrainiansthat has a significant positive influence on the process of structural change.

Subsequently, depending on the proportion of the life strategy types within Ukrainian society, the country has followed a number of development paths. The first is simple reproduction; the second is declining reproduction; and last is dynamic change (Reznik 13). The recent scholarly literature (especially Ukrainian and Russian) has typically distinguished only two models of life strategy: a strategy of achievement and a strategy of survival. It has emphasized that in the former Soviet Union the latter dominated (especially among older age groups). The given scholarship suggests that achievement strategies, being dynamic, risk-taking, future-oriented, and "creative," are typical for societies where individualism, free market economics and democratic governance dominate. In today's westernized societies, the strategy to achieve success in life can be seen as the most popular one.

The Ukrainian case, being representative of some other post-Soviet East European societies as well, demonstrates that post-independence Ukraine is not yet a purely individualistic, sovereign, and wholly democratic society. It 
is still on its way to becoming a welfare and egalitarian state, where people are not struggling for survival but are strong enough to compete for achievement and success. Likewise, life strategies of adaptation and survival are most prevalent in other "traditional" and crisis societies. When we apply the agency-structure approach to the Ukrainian case, one can clearly see that agency and agent practices have the power to determine the social and economic development of the country, and the speed and success of the democratic transition.

\section{CONCLUSION}

This broad literature review presents the main paradigms and highlights the limitation of the transition scholarship (both Western and post-Soviet East European) to produce an understanding of post-Soviet transitions given the combined agency-structure approach, which concentrates on social actors as individuals with their own set of resources and independent will, given particular structurally defined circumstances. As discussed above, the combined agency-structure approach runs contrary to the longstanding tendency in transition research to "underestimate the role of individual agency in shaping institutional change in novel and historically contingent ways" (Eyal et al. 40). It also challenges even the most recent post-Soviet Eastern European research that focuses more on groups than on individual agency, and demands new and fresh understanding and insights into the entire period of post-Soviet transition in Eastern Europe in a comparative perspective.

Several limitations of the recent attempts (which still are rare cases) to bring structure and agency together in understanding post-Communist transition and current dynamics in Eastern Europe are highlighted below:

- Mainstream attention is concentrated on the impact of society on the individual, rather than the reverse. Despite some great attempts in the post-Soviet East European transition scholarship (Ukrainian and Russian), the individual is still taken as an object of transition, rather than a subject. The traditional sociological approach to social transitions-though not ignoring the role of individuals in transition processes-has focused, and mainly still focuses, on the role of separate individuals in history, or examines the subject in the context of group interactions. Based on the idea that social reality is a constant interplay between macro (objective) and micro (subjective) processes, comprehended through an analysis of the components of reality, sociologists endeavour to "imagine the imagined," what Cooley has 
conceptualized as a "looking-glass self." The idea that individuals have the capacity to reflect on their own behaviours constitutes a subjective picture of social reality and indeed emphasizes its connection to objective reality (Cooley 41). In post-Soviet East European studies (Lapin et al. 6; Babenko, "Sotsial'nyi mekhanizm postsovetskoi transformatsii," 271), even when individual agency is taken into account, attention is still mainly directed from society to the individual, who is regarded as an object of transition rather than as its subject. The emphasis is on the individual only in terms of their capacity to adapt to new social realities.

- The focus of transition research is on community (group) agency rather than individual agency. It is important to mention that the vast majority of research on agency and structure that emerged in the 2000s in the post-Soviet countries, as well as in the West, focuses on community (or group) agency and underestimates individual agency. The role of individual agency as an agent of social change remained outside the focus of scholarly attention during all the 2000s. Instead, post-Soviet scholars offered a vision of society as a set of community associations and groups who were mainly joined horizontally (Honneth and Hans 222). This approach fitted with a postmodern paradigm of social development, which counters the classical idea of society as a single organism organized around a central hierarchical state with a vertical construction. Such an approach influenced the emergence of a new sociological vision in the post-Soviet East European scholarship around the dynamics of social processes as the results of efforts by different communities and groups as well as separate individuals (Zlobina and Tykhonovych 45). Though there is recognition of individual agency in the recent transition studies, the insights around group agency still supersede closer investigation of the role of individual agency.

Understanding the case of the transition in post-Communist Ukraine as applied in this paper prompts the following definition of a given system's transition, according to Mach, as

the interaction of organizational plans, oriented to the creation of collective identity of newly emerging system and the rules functioning of institutions it consists of, and individual plans, oriented to the creation of new individual identities and new rules of individual and structural functioning. (32)

This approach, and our brief discussion of the Ukrainian case, reinforce the idea that capitalism and democratic transition in Ukraine differs from its 
original, Western design and has been modified by the processes of adaptation and resistance of the people involved. Individual and group agency play key roles in the democratization of Ukraine. However, contrary to a tendency to "underestimate the role of agents in shaping institutional change in novel and historically contingent ways" (Eyal et al. 40), the Ukrainian case discussed above demonstrates that a theoretical understanding should explicitly concentrate on a combined focus on the social actors, who draw from all available resources (including those deriving from their socialist past) in their attempts to cope with changing social reality (Mach 25), and on the structural determinants of social actions. The case of Ukraine and its ongoing dynamics acknowledges the relative autonomy of the structural and cultural properties of a social system from the agency of the people involved. It is argued that the actions of social actors can be a good indicator of social, political, and economic changes in the institutional structure, and that individuals' life practices are just as important as structural parameters in determining their well-being (Whelan et al. 28). In this context and as discussed above, the reconstruction of a new socio-economic system in modern post-Euromaidan Ukraine is suggested as not merely background but also a possible new and different angle to the theoretical understanding of the transition research field, which needs constant monitoring and observation.

In sum, the retrospective analysis of transition research from the 1950s until the early 2010s presented in this paper shows that within the transition paradigm, popular in Eastern and Western European social science, scholars have found that the incorporation of such theoretical concepts as human agency and structural factors bears more fruit in capturing empirically and explaining theoretically the long-term effects of social change at individual and collective levels, as well as their residual effects on structural transformations.

\section{Works Cited}

Acemoglu, Daron, and James A. Robinson. Economic Origins of Dictatorship and Democracy. Cambridge UP, 2005.

Adamski, Wladyslaw. The Legacy of State Socialism as a Challenge to System Transformation. WZB, 1998.

Alexander, Neville. An Ordinary Country: Issues in the Transition from Apartheid to Democracy in South Africa. Berghahn Books, 2003

Andorka, Rudolf, and Zoltan Spéder. A magyar társadalom szerkezete. DKMPA, 1994.

Babenko, Svetlana (Svitlana) S. "Sotsial'nyi mekhanizm postsovetskoi transformatsii: deiatel'nostno-strukturnyi podkhod." Postkommunisticheskie transformatsii: vektory, napravleniia, soderzhanie, edited by O. D. Kutsenko and S. S. Babenko, Iz. 
tsentr Khar'kovskogo natsional'nogo universiteta imeni Karazina, 2004, pp. 25174.

---. "Sotsial'nyi mekhanizm transformatsii post-sovetskogo obshchestva: teoreticheskii analiz kontseptsii." Instytut Sotsiolohii NAN Ukrainy, Material Konfrenetsii, 2005, pp. 118-23.

Bauman, Zygmunt. Education: Under, for and in spite of Postmodernity. The Individualised Society. Blackwell Publishers, 2001.

Beck, Ulrich, Wolfgang Bonss, and Christoph Lau. "The Theory of Reflexive Modernization: Problematic, Hypotheses and Research Programme." Theory, Culture \& Society, vol. 20, no. 2, 2003, pp. 1-33.

Blume, Lawrence E., and Steven N. Durlauf, editors. The Economy as an Evolving Complex System, III: Current Perspectives and Future Directions. Oxford UP, 2006

Burnell, Peter. Does International Democracy Promotion Work? Dt. Inst. für Entwicklungspolitik, 2007. Discussion Paper.

Carothers, Thomas. "The End of the Transition Paradigm." Journal of Democracy, vol. 13, no. 1, 2002, pp. 5-21.

---. "How Democracies Emerge: The Sequencing Fallacy." Journal of Democracy, vol. 18, no. 1, 2007, pp. 12-27.

Carter, Bob, and Caroline New, editors. Making Realism Work: Realist Social Theory and Empirical Research. Routledge, 2005.

Collier, Ruth Berins, and David Collier. Shaping the Political Arena: Critical Junctures, the Labor Movement, and Regime Dynamics in Latin America. Princeton UP, 1991.

Cooley, Charles Horton. Human Nature and the Social Order. Scribner's, 1902.

Crouch, Colin, and Henry Farrell. "Breaking the Path of Institutional Development? Alternatives to the New Determinism." Rationality and society, vol. 16, no. 1, 2004, pp. 5-43.

Deutsch, Karl W. "Social Mobilization and Political Development." American Political Science Review, vol. 55, no. 3, 1961, pp. 493-514.

Domański, Henryk. "Major Social Transformations and Social Mobility: The Case of the Transition to and from Communism in Eastern Europe." Social Science Information, vol. 38, no. 3, 1999, pp. 463-91.

Durlauf, Steven N., and H. Peyton Young, editors. Social Dynamics. MIT P, 2004. Economic Learning and Social Evolution 4.

Eyal, Gil, et al. Making Capitalism without Capitalists: Class Formation and Elite Struggles in Post-Communist Central Europe. Verso, 1998.

"Dolia derzhavy u rukakh 16\% ukraintsiv." Shchodennyi L'viv, 12 Feb. 2013, http://dailylviv.com/news/41310?fb. Accessed 17 May 2018.

Frank, Andre Gunder. Latin America: Underdevelopment or Revolution. Monthly Review Press, 1969.

Giddens, Anthony. The Constitution of Society: Outline of the Theory of Structuration. Polity Press, 1984.

Golovakha, Evgenii, and Nataliia Panina. "Osnovnye etapy i tendentsii transformatsii ukrainskogo obshchestva: ot perestroiki do 'oranzhevoi revoliutsii."' Sotsiologiia: teoriia, metody, marketing, no. 3, 2006, pp. 32-51.

Hacker, Jacob. "The Institutional Foundations of Middle-Class Democracy." Policy Network, vol. 6, 2011, pp. 33-37. 
Honneth, Axel, and Hans Joas, editors. Communicative Action: Essays on Jürgen Habermas's The Theory of Communicative Action. MIT P, 1991.

Huntington, Samuel, P. The Third Wave: Democratization in the Late 20th Century. U of Oklahoma P, 1991.

Iadov, Vladimir A. "Rossiia kak transformiruiushcheesia obshchestvo (reziume mnogoletnei diskusii sotsiologov).” Obshchestvo i ekonomika, nos. 10-11, 1999, pp. 65-72.

Keller, Ian (Jan). "Modernizatsiia: gumanizatsiia obshchestva ili korroziia bytiia? Kriticheskie zametki o teorii modernizatsii." Sotsiologicheskie issledovaniia, vol. 7, no. 219, 2002, pp. 48-53.

Keller, Allister, and P. Joakim Westerholm. "Benchmarking a Transition Economy Capital Market." Australasian Accounting Business \& Finance Journal, vol. 1, no. 3, 2007, pp. 49-60.

Kohn, Melvin L., et al. "Social Structure and Personality during the Process of Radical Social Change: A Study of Ukraine in Transition." New Frontiers in Comparative Sociology, edited by Masamichi Sasaki, Brill, 2008, pp. 119-70.

Knack, Stephen. "Does Foreign Aid Promote Democracy?" International Studies Quarterly, vol. 48, no. 1, 2004, pp. 251-66.

Kutsenko, Olga (Ol'ha) D. "Deiatel'nostnaia perspektiva v ponimanii obshchestva: popytka deiatel'nostno-strukturnogo sinteza." Sotsiologiia: teoriia, metody, marketing, no. 1, 2001, pp. 27-41.

---. "Fazy i puti sistemnykh transformatsii: podobiia i razlichiia v byvshikh stranakh gosudarstvennogo sotsializma." Postkommunisticheskie transformatsii: vektory, napravleniia, soderzhanie, edited by O. D. Kutsenko and S. S. Babenko, Vyd. tsentr Kharkivs'koho natsional'noho universytetu imeni Karazina, 2004, pp. 251-74.

Kutsenko, Olga D., and Svetlana S. Babenko, editors. Postkommunisticheskie transformatsii: vektory, izmereniia, soderzhanie. Vyd. tsentr Kharkivs'koho natsional'noho universytetu imeni Karazina, 2004.

Lapin, Nikolai I., et al. Dinamika tsennostei naseleniia reformiruemoi Rossii. Editorial URSS, 1996.

Lerner, Daniel. The Passing of Traditional Society: Modernizing the Middle East. Free Press, 1958.

Levitsky, Steven, and Lucan Way. "The Rise of Competitive Authoritarianism." Journal of Democracy, vol. 13, no. 2, 2002, pp. 51-65.

Lipset, Seymour Martin. "The Social Requisites of Democracy Revisited: 1993 Presidential Address." American Sociological Review, 1994, pp. 1-22.

---. "Some Social Requisites of Democracy: Economic Development and Political Legitimacy." American Political Science Review, vol. 53, no. 1, 1959, pp. 69-105.

Mach, Bogdan W. Transformacja ustrojowa a mentalne dziedzictwo socjalizmu. Instytut Studiow Politycznych Polskiej Akademii Nauk, 1998.

Machonin, Pavel. Social Transformation and Modernization: On Building Theory of Societal Changes in the Post-Communist European Countries. Vol. 3, Sociologické nakladatelství, 1997.

Mahoney, James. "Path Dependence in Historical Sociology." Theory and Society, vol. 29, no. 4, 2000, pp. 507-48.

Mansfield, Edward D., and Jack Snyder. "Democratic Transitions, Institutional Strength, and War." International Organization, vol. 56, no. 2, 2002, pp. 297-337. 
McFaul, Michael, et al. Between Dictatorship and Democracy: Russian Post-Communist Political Reform. Carnegie Endowment, 2010.

Merkel, Wolfgang. "Embedded and Defective Democracies." Democratisation, vol. 11, no. 5, 2004, pp. 33-58.

---. Systemtransformation. Eine Einführung in die Theorie und Empirie der Transformationsforschung. VS Verlag für Sozialwissenschaften, 2010.

Moore, Barrington. Social Origins of Dictatorship and Democracy: Lord and Peasant in the Making of the Modern World. Beacon Press, 1966.

Mrozowicki, Adam. Coping with Social Change: Life Strategies of Workers in Poland's New Capitalism. Leuven UP, 2011.

Nathan, Andrew J. “Authoritarian Resilience.” Journal of Democracy, vol. 14, no. 1, 2003, pp. 6-17.

Naumova, Nataliia. "Zhiznennaia strategiia cheloveka v perekhodnom obshchestve." Sotsiologicheskii zhurnal, vol. 2, 1995, pp. 5-22.

O'Donnell, Guillermo, et al., editors. Transitions from Authoritarian Rule: Southern Europe. Johns Hopkins UP, 1986.

Ottaway, Marina. "Promoting Democracy after Conflict: The Difficult Choices." International Studies Perspectives, vol. 4, no. 3, 2003, pp. 314-22.

Panina, Nataliia. Ukrains'ke suspil'stvo 1992-2002. Sotsiolohichnyi monitorynh. Instytut sotsiolohii NAN Ukrainy, 2002.

Petrushina (Petrushyna), Tat'iana (Tetiana) O. Sotsial'no-ekonomicheskoe povedenie naseleniia Ukrainy $v$ usloviiakh institutsional'nykh peremen. Institut sotsiologii NAN Ukrainy, 2008.

Pierson, Paul. "Increasing Returns, Path Dependence, and the Study of Politics." American Political Science Review, vol. 94, no. 2, 2000, pp. 251-67.

Przeworski, Adam, et al. Democracy and Development: Political Institutions and Material Well-Being in the World, 1950-1990. Cambridge UP, 2000.

Pye, Lucian W. "Political Science and the Crisis of Authoritarianism." American Political Science Review, vol. 84, no. 1, 1990, pp. 3-19.

Reznik, Oleksandr S. Hromadians'ki praktyky v perekhidnomu suspil'stvi: chynnyky, sub"iekty, sposoby realizatsii. KIS NANU, 2011.

Reznik, Iurii M., and Evgenii A. Smirnov. Zhiznennye strategii lichnosti (opyt kompleksnogo analiza). Nezavisimyi institut grazhdanskogo obshchestva, 2002.

Rostow, Walt Whitman. The Stages of Economic Growth: A Non-Communist Manifesto. Cambridge UP, 1960.

Roxborough, Ian. "Modernization Theory Revisited. A Review Article." Comparative Studies in Society and History, vol. 30, no. 4, 1988, pp. 753-61.

---. Theories of Underdevelopment. MacMillan, 1979.

Schwartz, Herman. "Social Democracy Going down or down under: Institutions, Internationalized Capital, and Indebted States." Comparative Politics, vol. 30, no. 3, 1998, pp. 253-72.

Sztompka, Piotr. "Cultural Trauma: The Other Face of Social Change." The European Journal of Social Theory, vol. 3, no. 4, 2000, pp. 449-66.

Thelen, David. "Rethinking History and the Nation-State: Mexico and the United States." The Journal of American History, vol. 86, no. 2, 1999, pp. 438-55. 
Titarenko, Larisa. "Postsovetskaia transformatsiia demokratii: zapadnye i otechestvennye interpretatsii." Filosofiia i sotsial'nye nauki, no. 1, 2008, pp. 2127.

Toffler, Alvin. The Third Wave. Bantam Books, 1981.

Whelan, Christopher T., et al. Measuring Material Deprivation in the Enlarged European Union. Economic and Social Research Institute, 2008. ESRI Working Paper 249.

Wucherpfennig, Julian, and Franziska Deutsch. "Modernization and Democracy: Theories and Evidence Revisited." Living Reviews in Democracy, vol. 1, 2009, pp. 1-9.

Zakaria, Fareed. The Future of Freedom: Illiberal Democracy at Home and Abroad. Revised ed., WW Norton \& Company, 2003.

Zapf, Wolfgang. Modernization and Modernization Theories. Edition Sigma, 1994.

Zaslavskaia, Tat'iana I. O roli sotsial'noi struktury $v$ transformatsii rossiiskogo obshchestva. Kuda idet Rossiia? Moskovskaia Vysshaia shkola ekonomiki, 2000.

Zaslavskaia, Tat'iana I., and Vladimir A. Iadov. "Sotsial'nye transformaztsii v Rossii v epokhu global'nykh izmenenii." Sotsiologicheskii zhurnal, vol. 4, 2008, pp. 8-22.

Zlobina, Elena. "Lichnostnaia sostavliaiushchaia obshchestvennykh izmenenii: sotsiologicheskii kontekst." Sotsiologiia: teoriia, metody, marketing, no. 3, 2003, pp. 32-45.

Zlobina, Olena, and Volodymyr Tykhonovych. Syspil'na kryza i zhyttievi stratehii osobystosti. Stylos, 2001. 